DOI: 10.32844/2222-5374-2020-104-2.13

УДК: 342.56/342.9

Вишнева А. В.,

здобувач Науково-дослідного інституту публічного права

\title{
ІНСТИТУТ СУДДІВСЬКОГО ВРЯДУВАННЯ В УКРАЇНІ: ТЕОРЕТИКО-ПРАВОВИЙ АНАЛІЗ СУТНОСТІ
}

Відзначено, що забезпечення незалежності судів та суддів - це комплексний процес, що вимагає реалізації від низки суб'єктів різнобічних заходів щодо функціонування справедливого, безстороннього та неупередженого суду. Ключова роль у забезпеченні вказаного покладається саменаоргани суддівськоговрядуванняяквідповідальнихсуб'єктів, щомають повноваження як самостійно виконувати такі функції, так співпрацювати з іншими уповноваженими чи заінтересованими особами (органами) у процесі їх реалізації. Оскільки законодавчого та науково-доктринального висвітлення основ інституту суддівського врядування наразі досить мало, це спонукає до більш грунтовних наукових пошуків щодо виявлення його теоретико-правової сутності. Акцентовано, що хоч інститут суддівського врядування як самостійний, конституційний механізм забезпечення незалежності суддів в Україні тільки нещодавно отримав своє законодавче закріплення, однак він має довголітню історію становлення, перебуваючи сьогодні на етапі формування своєї функціональності. Сьогодні органи суддівського врядування вирішують та організовують процеси щодо забезпечення належної реалізації низки правових можливостей судової влади й охоронять (захищають, відстоюють) права суддів, що є прямо витікаючими зі змісту правового концепту «незалежність суддів в Україні». Визначено, що Вища рада правосуддя є вищим органом судової гілки влади в Україні у підзвітності якого є інші органи системи суддівського врядування, відносини між якими будуються на різнобічних рівнях та характеристиках. Підзвітність у цьому аспекті передбачає не керівництво діяльністю інших органів системи суддівського врядування в Україні, а те, що Вища рада правосуддя: 1) несе відповідальністьза стан реалізації незалежності судової системи, складових її структури плануючи свої дії, а також діяльність інших органів суддівського врядування на основі компромісу та балансу внутрішніх та зовнішніх факторів, формуючи нові адміністративні форми ведення діалогу; 2) залучає до вирішення питань сфери свої компетенції нових учасників (суб'єктів адміністративних повноважень) у тому числі шляхом делегування їм відповідальності за реалізацію конкретних напрямів забезпечення незалежності судової системи; 3) забезпечує комунікативну взаємодію між усіма уповноваженими та зацікавленими сторонами багатоступінчастих процесів представництва судової гілки влади.

Ключові слова: Вища кваліфікаційна комісія суддів України, Вища рада правосуддя, соціальна цінність, судді України, суддівське врядування, судова влада. 
Актуальність теми. Забезпечення незалежності судів та суддів - це комплексний процес, що вимагає реалізації від низки суб'єктів різнобічних заходів щодо функціонування справедливого, безстороннього та неупередженого суду. Ключова роль у забезпеченні вказаного покладається саме на органи суддівського врядування як відповідальних суб'єктів, що мають повноваження як самостійно виконувати такі функції, так співпрацювати 3 іншими уповноваженими чи заінтересованими особами (органами) у процесі їх реалізації. Втім законодавчого та науководоктринального висвітлення основ інституту суддівського врядування наразі досить мало, що спонукає до більш грунтовних наукових пошуків щодо його теоретико-правової сутності.

Аналіз останніх досліджень та публікацій. Актуалізація аналізованої проблематики, станом на сьогодні, надзвичайно висока. Річ у тім, що хоч окремі їі аспекти були предметом наукових пошуків таких вчених як Р. Абдулин, О. Боровицький, О. Гончаренко, В. Караваєв, М. Костецький, О. Курганський, Д. Мандичев тощо, однак у представленому для вивчення формулюванні вона висвітлена не була.

Виклад основного матеріалу. Вітчизняні вчені Л. Прокопенко, 0. Рудік, I. Шумляєва та Н. Рудік відзначають, що термін «врядування» відповідає так званій постмодерністській формі економічної і політичної організації суспільства. Він став широко вживатися в 90-х рр. такими міжнародними організаціями, як ООН, Світовий банк, МВФ. 3 визнанням важливості ефективного врядування для макроекономічного зростання та стабільності, МВФ та Світовий банк доповнили умови надання ними позик вимогами ефективного врядування та створення інституційних рамок вироблення економічної політики. В 1995 р. у межах новоствореної COT була сформульована нова категорія обов язкових вимог до державчленів цієї організації, які поширювались на багато сфер їх внутрішнього законодавства [1, с. 135].

Сьогодні тлумачні словники по-різному визначають зміст та значення даного терміну: існує трактування як застарілого аналогу до «орган правління» або дій з розпорядження чи виконання службових обов'язків [2, c. 484]. Але на сучасному етапі термін врядування частіше стає питанням дискусій в теорії управління. Проблемність виникає з урахуванням досвіду англомовних країн, де одночасно існують два терміни, government - урядового управління та governance - публічного (суспільного) управління, у якому задіяні усі зацікавлені сторони [3, с. 488; 4, с. 153].

Зокрема 3 погляду управлінського вектора, сучасна концепція врядування наголошує на системі цінностей, політик та інституцій, завдяки яким суспільство управляє своєю економікою, соціальними та політичними справами завдяки взаємодії держави, громадянського суспільства та бізнесу (приватного сектора). Врядування має три дійові сили: державу, яка створює сприятливі політико-правові умови, приватний сектор, який генерує робочі місця й доходи, та громадянське суспільство, яке посилює політичну та соціальну взаємодію. Метою розвитку стає не «сильна» або «мінімальна» держава - обидва ці підходи довели на практиці свою неспроможність, а ефективна держава. Остання перебуває в центрі економічного та соціального розвитку, однак уже не як безпосереднє 
джерело зростання, а як партнер, каталізатор та помічник, що стимулює та доповнює діяльність приватного бізнесу та окремих осіб [5, с. 4].

Відповідно, обов'язково при визначенні сутності категорії «суддівське врядування»слідвраховувати,щойого основа-термін «врядування»-єдуже багатогранним. Окрім теорії управління сьогодні він активно вживається в науковому обігу економічної та політичної наук, адже виник в результаті пошуку економічною наукою (корпоративне управляння) та політичною наукою (державне управління) всеосяжного поняття здатного вмістити у свій обсяг різноманітні значення, що не входили до традиційного поняття «уряд». Стосовно здійснення повноважень у цілому, термін «врядування», і в корпоративному, і в державно-управлінському контекстах, охоплює діяльність виконавчих, представницьких (національних парламентів) та судових органів [1, с. 134].

Тому цілком логічним є висновок О. Курганського, який стверджує, що сам термін «врядування», без демонстрації зв'язку з судом, суддями та судовою владою $є$ досить спірним та остаточно не знайшов свого загальновизнаного значення [4, с. 153].

У нормах чинного законодавства про інститут суддівського врядування в Україні згадується в контексті опису статусу інституцій, що покликані вирішувати абсолютно усі пов'язані із судами в Україні питання. Зокрема, це Вища кваліфікаційна комісія суддів та Вища рада правосуддя [6].

Уточнимо, що профільний законодавчий акт визначає Вищу раду правосуддя як колегіальний, незалежний конституційний орган державної влади та суддівського врядування, який діє в Україні на постійній основі для забезпечення незалежності судової влади, їі функціонування на засадах відповідальності, підзвітності перед суспільством, формування доброчесного та високопрофесійного корпусу суддів, додержання норм Конституції і законів України, а також професійної етики в діяльності суддів і прокурорів [7]. Водночас для здійснення конституційних функцій добору та оцінювання суддів функціонує Вища кваліфікаційна комісія суддів України, яка $€$ державним колегіальним органом суддівського врядування та діє на постійній основі у системі правосуддя України [8].

Слід звернути увагу, що законодавець з мінімальними розбіжностями вважає обидва органи, органами суддівського врядування, що не приносить єдності до розуміння даного терміну, та потребує подальшого наукового розроблення [4, с. 154]. Так, у рішенні Вищої ради правосуддя № 2128/0/15-20 від 14.07.2020 р. відзначено, що функції аналізованих органів частково дублюються, а тому доцільним у майбутньому є надати більш широкі повноваження Вищій раді правосуддя як конституційному органу. Саме на Вищу раду правосуддя як на конституційний орган суддівського врядування може бути покладено відповідальність за питання суддівської кар'єри від початку до ухвалення рішення про внесення відповідного подання суб'єкту призначення, а отже, покладено формування порядку щодо добору та кваліфікаційного оцінювання суддів, що на даний час віднесено до повноважень Вищої кваліфікаційної комісії суддів України [9].

Вказане узгоджується з рекомендаціями європейських інституцій. У 2007 році Венеційська комісія, надаючи висновок № 401/2006 стосовно 
проєктів законів про судоустрій і статус суддів, вказувала, що «немає потреби в окремій Вищій кваліфікаційній комісії і її повноваження необхідно передати Вищій раді юстиції, більшість якої складають судді» (пункт 23). На переконання Венеційської комісії, для забезпечення узгодженого підходу до судової кар'єри Вища кваліфікаційна комісія суддів України повинна стати частиною Вищої ради правосуддя, «можливо, як підрозділ, що відповідає за добір кандидатів на суддівські посади». При цьому Венеційська комісія також вказала, що не існує жодного європейського стандарту, який би визначав, що питання щодо призначення та кар'єри суддів повинні розглядатися одним органом (висновок Венеційської комісії щодо пропозицій внесення змін до законопроекту «Про внесення змін до Конституції України щодо посилення гарантій незалежності суддів» від 10 грудня 2013 року № C0I_-A0(2013)034, пункт 35) [9].

3 вищенаведених положень можна констатувати про доцільність сприйняття Вищої ради правосуддя як вищого органу судової гілки влади в Україні та центрального суб'єкта системи органів суддівського врядування у підзвітності якого є інші органи цієї системи, відносини між якими будуються на різнобічних рівнях та характеристиках. Підзвітність у цьому аспекті передбачає не керівництво діяльністю інших органів системи суддівського врядування в Україні, а те, що Вища рада правосуддя:

1) несе відповідальність за стан реалізації незалежності судової системи, складових її структури плануючи свої дії, а також діяльність інших органів суддівського врядування на основі компромісу та балансу внутрішніх та зовнішніх факторів, формуючи нові адміністративні форми ведення діалогу;

2) залучає до вирішення питань сфери свої компетенції нових учасників (суб'єктів адміністративних повноважень) у тому числі шляхом делегування їм відповідальності за реалізацію конкретних напрямів забезпечення незалежності судової системи;

3) забезпечує комунікативну взаємодію між усіма уповноваженими та зацікавленими сторонами багатоступінчастих процесів представництва судової гілки влади.

Цікавим $є$ те, що про необхідність існування аналізованого інституту висловлювався ще Р. Ієрінг. Так, він писав: «літописи юстиції мають велику кількість прикладів істинного героїзму з боку суддів, які боролися проти впливу сильних осіб, навіть, до втрати суддівського крісла; проте дуже важливо і для інтересів суспільства, і для інтересів приватних осіб, щоб справедливі рішення і вироки не були кожного разу актами героїзму з боку суддів, але спокійними міркуваннями звичайної людини, яка поставлена у можливість не боятися погроз земних влад і не прислуховуватися до думки ззовні, обов'язки якої чітко встановлені і з'ясовані: знати закон, враховувати факти і керуватися совістю» [10; 11, с. 19].

Як свого часу зазначав В. Караваєв, представник Національного інституту стратегічних досліджень, «для утвердження справедливого та неупередженого суду в Україні необхідно створити сприятливі умови для перетворення Вищої ради юстиції в автономний управлінський орган, який забезпечить формування високопрофесійного й відповідального суддівського корпусу, гарантування його незалежності при здійсненні 
правосуддя» [12]. Як стверджує вчений, «у зв’язку зі зміною статусу Вищої ради юстиції (формування її складу, зміна її повноважень, передача повноважень Вищої кваліфікаційної комісії суддів України до сфери їі відання тощо) постає потреба й приведення назви фактично новостворюваного конституційного органу у відповідність до низки висновків Венеціанської комісії та Консультативної ради європейських суддів - Рада судової влади України, Вища рада правосуддя України чи Вища судова рада України» [12; 13].

Додамо, що на думку Венеціанської комісії, «немає якоїсь стандартної моделі, якій мала б слідувати демократична країна при створенні ради юстиції, аби лиш функціонування такої ради досягало мети забезпечення належного функціонування незалежної судової системи в демократичній державі. Хоча існують моделі, в якихучасть інших гілок влади (законодавчої та виконавчої) в діяльності рад юстиції категорично виключена або зведена до мінімуму, в більшості національних законодавств така участь все ж якоюсь мірою визнається і виправдовується суспільним контекстом функцій вищої ради юстиції та потребою в тому, щоб інші гілки державної влади здійснювали моніторинг адміністративної діяльності судової влади. Очевидно, що судова влада має бути в рамках закону відповідальною за свої дії, за умови наявності відповідної справедливої та належної процедури і можливості звільнення судді з посади лише на доведених підставах. Утім, загалом вважається, що основною метою існування вищої ради юстиції $\epsilon$ захист незалежності суддів шляхом ізолювання їх від неналежного тиску інших гілок державної влади в таких питаннях, як добір і призначення суддів та здійснення дисциплінарних функцій (....)» [14].

Відповідно, проведення в Україні чергової конституційної реформи у 2016 р. призвело до внесення суттєвих змін до статусу Вищої ради юстиції та Вищої кваліфікаційної комісії суддів. Зокрема, в законі України «Про внесення змін до Конституції України (щодо правосуддя)» [15] було враховано майже всі рекомендації, надані органами Ради Європи (Парламентською Асамблеєю, Комітетом Міністрів, Європейським судом 3 прав людини, Венеціанською комісією тощо) щодо провадження судової реформи в Україні, серед яких значна частина стосувалася порядку та способу формування Вищої ради юстиції (правосуддя). Було враховано рекомендації щодо: 1) необхідності створення незалежного від виконавчої та законодавчої влади органу, який відповідав би за призначення й кар'єру суддів; 2) того, що більшість членів Вищої ради юстиції (правосуддя) чи принаймні істотну їх частину повинні складати судді; 3) забезпечення обрання членів Вищої ради правосуддя, які не є суддями, серед інших видатних юристів, університетських професорів із певним стажем перебування на посаді або звичайних громадян. I лише одна рекомендація так і не була врахована це об’єднання Вищої ради юстиції та Вищої кваліфікаційної комісії суддів в один орган [16; 17, с. 43-44]. Натомість розпочата у 2019 році судова реформа сфокусувала свою увагу на перезавантаженні Вищої кваліфікаційної комісії суддів [18], що мало наслідком запровадження нового порядку формування цього органу.

Висновок. Хоч інститут суддівського врядування як самостійний, конституційний механізм забезпечення незалежності суддів в Україні 
тільки нещодавно отримав своє законодавче закріплення, однак він має довголітню історію становлення, перебуваючи сьогодні на етапі формування своєї функціональності. Сьогодні органи суддівського врядування вирішують та організовують процеси щодо забезпечення належної реалізації низки правових можливостей судової влади й охоронять (захищають, відстоюють) права суддів, що є прямо витікаючими зі змісту правового концепту «незалежність суддів в Україні».

\section{СПИСОК ВИКОРИСТАНИХ ДЖЕРЕЛ}

1. Теорія та практика європейського врядування : навч. посіб.; Л.Л. Прокопенко, О.М. Рудік, І.Д. Шумляєва, Н.М. Рудік. Д.: ДРІДУ НАДХ 2009. $216 \mathrm{c}$.

2. Енциклопедія державного управління у 8-ми томах. Том 8: Публічне врядування; наук. ред. колегія: В.С. Загорський (голова), С.0. Телешун (співголова) та ін. Львівський регіональний інститут державного управління Національної академії державного управління при Президентові України. Львів : ЛРІДУ НАДУ, 2011.630 с.

3. Абдулин Р. С. Судебное управление как структурно-функциональный элемент в системе советского государственного управления. Genesis: исторические исследования. 2014. № 3. С. 16-36.

4. Курганський О. В. До питання щодо суддівського врядування. Творчий шлях вченого: до 80-річчя професора В.В. Долежана : матер. кругл. столу; відп. ред. Н.М. Бакаянова ; уклад.: I.О. Кісліцина, М.О. Деменчук, C.I. Єленич; МОН України, НУ «ОЮА». Одеса : Юридична література, 2018. C. $152-154$.

5. Економіка та врядування: метод. рек. для підготовки фахівців за ступенем вищої освіти «Магістр»; уклад. : Горник В.Г., І.В. Бовсунівська. К. : УкрСІЧ, 2019. 26 с.

6. Костецький М. Хаос і перспективи суддівського врядування. Трансперенсі Інтернешнл Україна. 2019. URL: https://ti-ukraine.org/blogs/haos-iperspektyvy-suddivskogo-vryaduvannya/

7. Про Вищу раду правосуддя: Закон України від 21.12.2016 № 1798VIII. Офіційний вісник України. 2017 р., № 4, стор. 180, стаття 107, код акта $84481 / 2017$

8. Рішення Конституційного Суду України у справі за конституційним поданням Верховного Суду щодо відповідності Конституції України (конституційності) окремих положень [...] від 11.03.2020 № 4-p/2020. Верховна Рада України. URL: https://zakon.rada.gov.ua/laws/show/v004p71020\#Text

9. Про надання консультативного висновку до законопроєкту № 3711-2: Рішення Вищої ради правосуддя від 14.07.2020 р., № 2128/0/1520. Вища рада правосуддя. URL: https://hcj.gov.ua/doc/doc/3689

10. Иеринг Р. Борьба за право. М.: Феникс, 1991. 64 с.

11. Гончаренко О.В. Виникнення органів державного управління у процесі формування судового корпусу. Університет. Історико-філософський журнал. 2007. № 5. С. 7-21.

12. Караваєв В.С. Щодо вдосконалення конституційного статусу Вищої ради юстиції. Аналітична записка. 2014. URL: https://niss.gov.ua/ 
doslidzhennya/politika/schodo-vdoskonalennyakonstituciynogo-statusuvischoi-radi-yusticii\#_ftn19

13. Боровицький О. А. Генезис правових засад діяльності Вищої ради правосуддя як органу забезпечення незалежності суддів. Науковий огляд. 2020. № 2(65). С. 28-48.

14. Доповідь Європейської комісії «За демократію через право» (Венеціанської комісії) щодо призначення суддів. Венеція, 22 червня 2007 року Висновок № 403/2006 CDL-AD(2007)028. URL: https://www. vkksu.gov.ua/userfiles/doc/perelik-dokumentiv/dop-evr-kom.pdf

15. Про внесення змін до Конституції України (щодо правосуддя): закон України від 02.06.2016 № 1401-VIII. Відомості Верховної Ради України. 2016. № 28. Ст. 532

16. Список рекомендацій Ради Європи щодо судової реформи і реформи прокуратури в Україні. Центр політико-правових реформ. URL: http:// pravo.org.ua/ua/news/5000-

17. Мандичев Д. В. Місце Вищої кваліфікаційної комісії суддів та Вищої ради правосуддя в організації роботи господарських судів. Право і безпека. 2017. № 2(65). С. 43-47.

18. Пояснювальна записка до проекту Закону України «Про внесення змін до Закону України «Про судоустрій і статус суддів» та деяких законів України щодо діяльності Верховного Суду та органів суддівського врядування» від 07.07.2020 № 3711-1. ЛігаЗакон. URL: https://ips.ligazakon. net/document/GI02648A?an=20.

\section{A. Vyshneva}

\section{INSTITUTE OF JUDICIAL GOVERNANCE IN UKRAINE: THEORETICAL AND LEGAL ANALYSIS OF ESSENCE}

It is noted that ensuring independence of courts and judges is a complex process. It requires implement a variety of measures to ensure functioning of a fair, impartial and impartial tribunal. The key role in ensuring this rests with the judicial governance. These are responsible entities that have the authority to perform such functions independently, as well as to cooperate with other authorized or interested persons (bodies) in the process of their implementation. As the legislative and scientific-doctrinal coverage of the foundations of the institute of judicial governance is currently quite small, this encourages a more thorough scientific search for its theoretical and legal essence. It is emphasized that although the institution of judicial governance as an independent, constitutional mechanism for ensuring the independence of judges in Ukraine has only recently been enshrined in law, but it has a long history of formation, being today at the stage of formation of its functionality. Today, authorities of judicial governance decide and organize processes to ensure the proper implementation of a number of legal opportunities of the judiciary and protect (defend) the rights of judges, which are directly derived from the content of the legal concept of "independence of judges in Ukraine". It is determined that the High Council of Justice is the highest body of the judiciary in Ukraine, which is accountable to other bodies of judicial system, relationship between which is built on various levels and characteristics. Accountability in this 
aspect does not imply the management of other bodies of judicial system in Ukraine, but the fact that the High Council of Justice: 1) is responsible for implementation of judiciary independence, its components planning its actions, as well as the activities of other bodies on the basis of compromise and balance of internal and external factors, forming new administrative forms of dialogue; 2) involves new participants (subjects of administrative powers) in the solution of issues sphere of competence, including by delegating to them the responsibility for implementation of specific areas of ensuring the independence of the judiciary; 3) provides communicative interaction between all authorized and interested parties of multi-stage processes of representation of the judiciary.

Keywords: High Council of Justice, High Qualification Commission of Judges of Ukraine, judges of Ukraine, judicial governance, judiciary, social value. 